\title{
Fruit-Growing and Research.
}

THE application of scientific methods and principles is steadily gaining ground in fruit culture as in other branches of agriculture, and the numerous publications on the subject provide evidence of a widening interest in the matter, both as regards the scientific and the practical worker.

The earlier work of Spencer Pickering and the Duke of Bedford stimulated interest in the root systems of fruit trees, and at Long Ashton ${ }^{1}$ the matter of root development under various conditions is being followed up. It appears that the method of treatment at the time of planting has little effect on the type of root produced, a new root system being derived from the collar region of the tree and little growth occurring elsewhere; aeration is considered to be a dominant factor in determining the actual point of origin of the new roots. Root formation and growth are most active at the beginning and towards the end of the season, the greatest increase in root length occurring during the latter period, at the time when shoot growth is rapidly decreasing. Other experiments deal with the extension of the root system throughout the soil, a matter which has a direct bearing on the degree of overlapping of roots when too close planting is practised.

On the pathological side special attention has been directed to leaf-scorch on fruit trees, and the trouble has been found to be due to various causative agents. Among the chief of these are unfavourable soil conditions, due to deficient food or water supply or to defective aeration owing to the mechanical character of the soil. Scorching is also attributed to the direct action of wind, to excessive heat falling on the leaf, or to injury to the vascular system of the plant, such as may be caused by ringing or by the presence of a fungus which penetrates the vascular tissue and interferes with the water supply to the leaves.

The importance of spraying to combat disease is now widely recognised, and at East Malling ${ }^{2}$ direct 1 Annual Report of the Agricultural and Horticultural Research Station, Long Ashton, 1921.

2 Grubb, N. H. (rg2I), Journal of Pomology, II., No. 2. experimental work is being carried out with fungicides on apple trees. Every fungicide tested reduces apple scab (Venturia incqualis), though the degree of effectiveness varies, Bordeaux mixture usually proving the best. Generally speaking, the crop and the size of the fruit are improved by spraying, with certain. exceptions, and there are indications that summer spraying may improve the keeping quality of the fruit by reducing attacks of brown-rot (Sclevotinia fructigens). An interesting point is that the effects of spraying are cumulative, sprayed trees being less heavily affected in the succeeding years.

A critical examination of the stocks used for stone fruits ${ }^{3}$ shows that little or no attempt has hitherto been made to group them as has been done for those used for apples and pears, rapidity of growth and general availability being usually the deciding factors in the selection of stocks in any particular instance. The descriptions worked out at East Malling are the beginnings of an attempt to set up a permanent standard of classification and identification with the view of the ultimate improvement of stone fruit cultivation.

In an interesting survey on progress in methods of practical fruit-growing in the Journal of the Royal Agricultural Society of England, ${ }^{4}$ the whole business, from the selection of a holding to the final packing of the fruit, is traced. Laying out and planting the fruit farm, raising and selecting trees, pruning, manuring, diseases, and pests are all brought under consideration in a way that provides suggestive reading for all interested in the subject, and its value is enhanced by a useful bibliography. In this connexion also attention may be directed to the collected leaflets ${ }^{5}$ on fruit recently reissued by the Ministry of Agriculture, in which various problems the practical fruit-grower encounters in his work receive detailed consideration.

3 Hatton, H. G. (r92r), Journal of Pomology, II., No. 4.

5 Collected Leaflets on Fruit, I92r. Sectional volumes, No. 4. Ministry of Agriculture and Fisheries.

\section{Volcanic Activity in Nigeria.} N NATURE of July 15, p. 97, an account was given
of volcanic activity in Nigeria during MarchMay last. The following extracts, from the reports of Mr. H. S. Cameron, acting Supervisor of Plantations in Nigeria, furnish some later information. They are placed at our disposal through the courtesy of the Colonial Office :-

On June $I_{7}$ the manager of Bibundi informed me by telephone that lava streams had commenced to flow again; also that heavy damage was being done by floods. On June 18 I went to Bibundi, and going by trolley to Dollmanshöhe I found the roadway of the bridge entirely swept away by floods and also one of the four piers gone. I went up the river, and after about a mile reached the first flow of lava, which had been advancing the day before but had now cooled and was stationary. Crossing from there to Wernerfelde, progress was shortly prevented by advancing lava; the stream here was molten, but its advance, which was more "creeping" than "flowing," was over a very wide area and on a gentle slope, and it seemed probable that eventually it would cool and turn the main lava stream down the old course of the Njonge river and extend into the sea, as part of the flow was then doing.
The flooding damage was considerable and I think unpreventable; the amount of water is so great that it is impossible to direct it. More than fifty inches of rain fell in the first seventeen days of June, and the water from an area which formerly fed three rivers and part of a fourth has now no channel: not only is an exit lacking, but rain falling on lava does not sink in and percolate through but rushes at once to the lowest level, so free drainage is more necessary than ever.

On June $22 \mathrm{I}$ received a letter stating that the lava had broken through near Dollmanshöhe bungalow, followed the course of the stream, and was threatening the hospital, which had been abandoned. On reaching the bridge-end at Dollmanshöhe on June 25, I found that the whole of that division above the iron road had been covered with lava, and cascades of molten lava were flowing down the banks of the ravine. It was really a wonderful sight. The river bed was full of detached flows of lava fed from the Dollmanshöhe plateau, where it had been massing during the past week. I inspected the whole length from near the Thormählenfelde bungalow to the director's house, finding flowing lava everywhere. By afternoon the ravine was filled, and by II P.M. the lava had crossed the rail where the Government road turns

NO. 2762 , VOL. I IO] 